\title{
Sphingosinicella soli sp. nov., isolated from an alkaline soil in Korea
}

\author{
Jung-Hoon Yoon, ${ }^{1}$ So-Jung Kang, ${ }^{1}$ Jung-Sook Lee, ${ }^{1}$ Sun-Woo Nam, ${ }^{2}$ \\ Wonyong $\mathrm{Kim}^{3}$ and Tae-Kwang $\mathrm{Oh}^{1}$ \\ ${ }^{1}$ Korea Research Institute of Bioscience and Biotechnology (KRIBB), PO Box 115, Yusong, Taejon, \\ Republic of Korea \\ ${ }^{2}$ Health Technology Planning and Evaluation Board, 57-1 Noryangjin-dong, Seoul, Republic of \\ Korea \\ ${ }^{3}$ Department of Microbiology, College of Medicine, Chungang University, 221 Heukseok-dong, \\ Seoul, Republic of Korea
}

Correspondence

Jung-Hoon Yoon

jhyoon@kribb.re.kr
A Gram-negative, motile, rod-shaped bacterial strain, $\mathrm{KSL}-125^{\top}$, was isolated from an alkaline soil from Kwangchun, Korea, and its taxonomic position was investigated in a polyphasic study. Strain $\mathrm{KSL}-125^{\top}$ grew optimally at $30{ }^{\circ} \mathrm{C}$, at $\mathrm{pH} 7.5-8.0$ and in the presence of $0.5 \%(\mathrm{w} / \mathrm{v}) \mathrm{NaCl}$.

A neighbour-joining phylogenetic tree based on 16S rRNA gene sequences showed that strain $\mathrm{KSL}-125^{\top}$ joins the cluster comprising the two Sphingosinicella species at a bootstrap resampling value of $100 \%$. The values for similarity between the $16 \mathrm{~S}$ rRNA gene sequence of strain KSL-125 $5^{\top}$ and those of the type strains of the two Sphingosinicella species were 98.9-99.0\%. Strain KSL-125 ${ }^{\top}$ contained $\mathrm{Q}-10$ as the predominant ubiquinone and $\mathrm{C}_{17: 1} \omega 6 c$, $\mathrm{C}_{16: 1} \omega 7 c$ and/or iso- $\mathrm{C}_{15: 0} 2-\mathrm{OH}$ and $\mathrm{C}_{18: 1} \omega 7 c$ as the major fatty acids. The major polar lipids were sphingoglycolipid, diphosphatidylglycerol, phosphatidylglycerol, phosphatidylethanolamine, phosphatidylmonomethylethanolamine and an unidentified phospholipid. The DNA G+C content was $65.1 \mathrm{~mol} \%$. Strain KSL-125 ${ }^{\top}$ was distinguishable from the two recognized Sphingosinicella species on the basis of differential phenotypic properties, DNA-DNA relatedness data and repetitive-sequence-based PCR genomic fingerprinting patterns. The phenotypic, phylogenetic and genetic data showed that strain $\mathrm{KSL}-125^{\top}$ represents a novel species of the genus Sphingosinicella, for which the name Sphingosinicella soli sp. nov. is proposed. The type strain is KSL-125 $5^{\top}\left(=\right.$ KCTC $12482^{\top}=$ DSM $\left.17328^{\top}\right)$.
The genus Sphingosinicella was proposed by Maruyama et al. (2006) with the description of a single species, Sphingosinicella microcystinivorans, as a novel member of the family Sphingomonadaceae. Subsequently, another Sphingosinicella species, Sphingosinicella xenopeptidilytica, was described (Geueke et al., 2007). Here we report on the taxonomic characterization of a Sphingosinicella-like bacterial strain, KSL- $125^{\mathrm{T}}$, which was isolated from an alkaline soil in Korea.

An alkaline soil collected from Kwangchun, Korea, was used as the source for the isolation of bacterial strains. Strain KSL-125 $5^{\mathrm{T}}$ was isolated with the usual dilution plating technique on $10 \times$ diluted nutrient agar (Difco) at

Abbreviation: rep-PCR, repetitive-sequence-based PCR.

The GenBank/EMBL/DDBJ accession number for the $16 \mathrm{~S}$ rRNA gene sequence of strain $\mathrm{KSL}-125^{\top}$ is DQ087403.

Biolog assimilation data for strain $\mathrm{KSL}-125^{\top}$ and the two Sphingosinicella species are presented in a supplementary table available with the online version of this paper.
$30{ }^{\circ} \mathrm{C}$. The type strains of the two Sphingosinicella species were used as reference strains: S. microcystinivorans KCTC $12019^{\mathrm{T}}$ was obtained from the Korean Collection for Type Cultures (Taejon, Korea) and S. xenopeptidilytica 3-2W4 ${ }^{\mathrm{T}}$ was obtained from H.-J. Busse (Geueke et al., 2007). To investigate its morphological, physiological and biochemical characteristics, strain KSL- $125^{\mathrm{T}}$ was routinely cultivated at $30{ }^{\circ} \mathrm{C}$ on trypticase soy agar (TSA; Difco). The cell morphology was examined using light microscopy (E600; Nikon) and the presence of flagella was investigated using transmission electron microscopy with cells from exponentially growing cultures. The Gram reaction was determined by using the bioMérieux Gram stain kit according to the manufacturer's instructions. Growth in the absence of $\mathrm{NaCl}$ and at various $\mathrm{NaCl}$ concentrations $(0.5,1.0,2.0,3.0,4.0$ and $5.0 \%, \mathrm{w} / \mathrm{v})$ was investigated in trypticase soy broth prepared according to the formula of the Difco medium except that $\mathrm{NaCl}$ was excluded. Growth at various temperatures $\left(4-45{ }^{\circ} \mathrm{C}\right)$ was measured on TSA. The $\mathrm{pH}$ range for growth was determined in nutrient broth 
(Difco) adjusted to various pHs (initial $\mathrm{pH} 4.5-10.5$, in increments of $0.5 \mathrm{pH}$ units). The $\mathrm{pH}$ was adjusted to various levels prior to sterilization by the addition of $\mathrm{HCl}$ or $\mathrm{Na}_{2} \mathrm{CO}_{3}$. Growth under anaerobic conditions was determined after incubation in an anaerobic chamber on TSA and on TSA supplemented with nitrate, both of which had been prepared anaerobically using nitrogen. Catalase and oxidase activities and the hydrolysis of casein, starch, hypoxanthine, tyrosine, xanthine and Tweens 20, 40, 60 and 80 were determined as described by Cowan \& Steel (1965). Hydrolysis of aesculin, gelatin and urea and reduction of nitrate were studied as described previously (Lanyi, 1987). Assimilation of various substrates was determined by using the Biolog GN2 MicroPlate assay as recommended by the manufacturer. Assimilation results were checked after 3 days. Enzyme activity was determined by using the API ZYM system (bioMérieux). Susceptibility to antibiotics was tested on TSA plates using antibiotic discs containing the following: polymyxin B, $100 \mathrm{U}$; streptomycin, $50 \mu \mathrm{g}$; penicillin G, $20 \mathrm{U}$; chloramphenicol, $100 \mu \mathrm{g}$; ampicillin, $10 \mu \mathrm{g}$; cephalothin, $30 \mu \mathrm{g}$; gentamicin, $30 \mu \mathrm{g}$; novobiocin, $5 \mu \mathrm{g}$; tetracycline, $30 \mu \mathrm{g}$; kanamycin, $30 \mu \mathrm{g}$; lincomycin, $15 \mu \mathrm{g}$; oleandomycin, $15 \mu \mathrm{g}$; neomycin, $30 \mu \mathrm{g}$; carbenicillin, $100 \mu \mathrm{g}$. Other physiological and biochemical tests were performed with the API 20E system (bioMérieux). The occurrence of genes $m \operatorname{lr} A, m \operatorname{lr} B, m l r C$, $m l r D$ and puf was investigated by using primers and conditions described previously (Saito et al., 2003; Geueke et al., 2007); S. microcystinivorans KCTC $12019^{\mathrm{T}}$ and S. xenopeptidilytica $3-2 \mathrm{~W} 4^{\mathrm{T}}$ were used as positive or negative controls.

Cell biomass for DNA extraction and for the analyses of isoprenoid quinones and polar lipids was obtained from cultivation at $30{ }^{\circ} \mathrm{C}$ in trypticase soy broth (Difco) supplemented with $1 \%(\mathrm{v} / \mathrm{v})$ Hutner's mineral base (Cohen-Bazire et al., 1957). Chromosomal DNA was isolated and purified according to the method described by Yoon et al. (1996) except that RNase T1 was used in combination with RNase A. The $16 \mathrm{~S}$ rRNA gene was amplified by using a PCR with two universal primers as described previously (Yoon et al., 1998). Sequencing of the amplified 16S rRNA gene and phylogenetic analysis were performed as described by Yoon et al. (2003). The DNA $\mathrm{G}+\mathrm{C}$ content was determined by using the method of Tamaoka \& Komagata (1984) with the modification that DNA was hydrolysed and the resulting nucleotides were analysed by reversed-phase HPLC. Isoprenoid quinones were extracted according to the method of Komagata \& Suzuki (1987) and were analysed using reversed-phase HPLC and a YMC ODS-A $(250 \times 4.6 \mathrm{~mm})$ column. Polar lipids were extracted according to the procedures described by Minnikin et al. (1984) and were identified by using twodimensional TLC followed by spraying with the appropriate detection reagents (Minnikin et al., 1984; Komagata \& Suzuki, 1987). For fatty acid methyl ester analyses, cell mass of strain KSL- $125^{\mathrm{T}}$, S. microcystinivorans KCTC $12019^{\mathrm{T}}$ and S. xenopeptidilytica $3-2 \mathrm{~W} 4^{\mathrm{T}}$ was harvested from TSA plates after cultivation for 7 days at $30{ }^{\circ} \mathrm{C}$. The fatty acids were extracted and fatty acid methyl esters were prepared according to the standard protocol of the MIDI/ Hewlett Packard Microbial Identification System (Sasser, 1990). Repetitive-sequence-based PCR (rep-PCR) genomic fingerprinting using REP, ERIC, BOX, (GTG) $)_{5}$ and SERE PCR primers was performed as described previously (Versalovic et al., 1994; Rademaker et al., 1998; Rajashekara et al., 1998). Computer-assisted analysis of the genomic fingerprints was performed by using GelCompar II (version 1.5) software (Applied Maths). Similarity among the patterns was calculated using Pearson's similarity coefficient and the dendrogram was constructed using the UPGMA algorithm (Sneath \& Sokal, 1973).

Morphological, cultural, physiological and biochemical properties of strain KSL- $125^{\mathrm{T}}$ are shown in Table 1 and Supplementary Table S1 (available in IJSEM Online) or are given in the species description. The almost-complete $16 \mathrm{~S}$ rRNA gene sequence of strain KSL- $125^{\mathrm{T}}$ determined in this study comprised $1409 \mathrm{nt}$ (representing approximately $96 \%$ of the Escherichia coli 16S rRNA gene sequence). Comparative 16S rRNA gene sequence analyses showed that strain KSL- $125^{\mathrm{T}}$ is phylogenetically closely related to the family Sphingomonadaceae of the Alphaproteobacteria (Fig. 1). In the phylogenetic tree based on the neighbourjoining algorithm, strain KSL- $125^{\mathrm{T}}$ joined the cluster comprising the two Sphingosinicella species with $100 \%$ bootstrap support (Fig. 1). The $16 \mathrm{~S}$ rRNA gene sequence of strain KSL- $125^{\mathrm{T}}$ shared the same signature nucleotides as those defined for the genus Sphingosinicella, as described by Geueke et al. (2007). Strain KSL-125 $5^{\mathrm{T}}$ exhibited $16 \mathrm{~S}$ rRNA gene sequence similarity values of 98.9 and $99.0 \%$ with respect to the type strains of $S$. microcystinivorans and $S$. xenopeptidilytica, respectively, and showed less than $94.2 \%$ sequence similarity with respect to other species used in the phylogenetic analysis. Chemotaxonomic properties confirm the phylogenetic affiliation of strain KSL- $125^{\mathrm{T}}$ as a member of the genus Sphingosinicella. The predominant isoprenoid quinone detected in strain KSL- $125^{\mathrm{T}}$ was Q-10 (at a peak area ratio of approximately $90 \%$ ) and minor amounts of Q-8 and Q-9 were also present. Strain KSL$125^{\mathrm{T}}$ had a cellular fatty acid profile comprising large amounts of unsaturated, hydroxy and straight-chain fatty acids; the major fatty acids ( $>10 \%$ total fatty acids) were $\mathrm{C}_{17: 1} \omega 6 c(27.7 \%), \mathrm{C}_{16: 1} \omega 7 c$ and/or iso- $\mathrm{C}_{15: 0} \quad 2-\mathrm{OH}$ $(23.3 \%)$ and $\mathrm{C}_{18: 1} \omega 7 c(19.0 \%)$. This cellular fatty acid profile was generally similar to those of the two Sphingosinicella species, but was distinguishable from them in terms of the contents of some fatty acids, particularly $\mathrm{C}_{17: 1} \omega 6 c$, which was present as a major component in strain KSL- $125^{\mathrm{T}}$ but was only a minor component in the two Sphingosinicella species (Table 2). The major polar lipids detected in strain KSL- $125^{\mathrm{T}}$ were sphingoglycolipid, diphosphatidylglycerol, phosphatidylglycerol, phosphatidylethanolamine, phosphatidylmonomethylethanolamine and an unidentified phospholipid; a minor amount of an 
Table 1. Differential phenotypic characteristics of Sphingosinicella species

Strains: 1, strain KSL- $125^{\mathrm{T}}$; 2, S. microcystinivorans KCTC $12019^{\mathrm{T}}$; 3 , S. xenopeptidilytica $3-2 \mathrm{~W} 4^{\mathrm{T}}$. Data for reference strains are from this study unless indicated. All strains were positive for catalase, oxidase, alkaline phosphatase, esterase (C4), esterase lipase (C8), leucine arylamidase and $\mathrm{N}$-acetyl- $\beta$-glucosaminidase. All strains were negative for the Gram stain and for urease, arginine dihydrolase, indole production, hydrolysis of aesculin and gelatin, lipase (C14), cystine arylamidase, trypsin, naphthol-AS-BI-phosphohydrolase, $\alpha$-galactosidase, $\beta$-galactosidase, $\beta$-glucuronidase, $\alpha$-glucosidase, $\beta$-glucosidase, $\alpha$-mannosidase and $\alpha$-fucosidase. The $m l r D$ gene was detected by PCR in all strains, but the $m l r C$ gene was not detected. +, Positive; - , negative; $\mathrm{w}$, weakly positive.

\begin{tabular}{|c|c|c|c|}
\hline Characteristic & 1 & 2 & 3 \\
\hline Nitrate reduction & - & + & + \\
\hline Growth at $2.5 \%(\mathrm{w} / \mathrm{v}) \mathrm{NaCl}$ & - & $-{ }^{a \star}$ & $+^{b}$ \\
\hline $\begin{array}{l}\text { Two red pigments in polar lipid } \\
\text { extract }\end{array}$ & - & $-^{a}$ & $++^{b}$ \\
\hline Production of $\mathrm{H}_{2} \mathrm{~S}$ & - & - & $++^{b}$ \\
\hline Hydrolysis of Tween 80 & + & - & $-{ }^{b}$ \\
\hline \multicolumn{4}{|l|}{ Detection (by PCR) of: } \\
\hline$m l r A$ & - & $+{ }^{a}$ & $-{ }^{b}$ \\
\hline$m l r B$ & - & $+{ }^{a}$ & $-{ }^{b}$ \\
\hline puf & - & $+{ }^{a}$ & $-{ }^{b}$ \\
\hline \multicolumn{4}{|l|}{ Assimilation of: } \\
\hline Tween 40 & - & + & - \\
\hline Tween 80 & - & + & - \\
\hline Methyl pyruvate & + & + & - \\
\hline Monomethyl succinate & - & + & - \\
\hline D-Galacturonic acid & - & + & - \\
\hline$\alpha$-Hydroxybutyric acid & - & + & + \\
\hline p-Hydroxyphenylacetic acid & - & + & - \\
\hline$\alpha$-Ketobutyric acid & - & + & + \\
\hline$\alpha$-Ketoglutaric acid & - & - & + \\
\hline$\alpha$-Ketovaleric acid & + & + & - \\
\hline DL-Lactic acid & - & + & + \\
\hline Glycyl L-aspartic acid & - & - & + \\
\hline L-Ornithine & + & - & - \\
\hline L-Proline & - & + & + \\
\hline D-Serine & - & + & - \\
\hline L-Threonine & - & + & - \\
\hline DL- $\alpha$-Glycerol phosphate & - & - & + \\
\hline Glucose 1-phosphate & - & - & + \\
\hline \multicolumn{4}{|l|}{ Enzyme activity (API ZYM): } \\
\hline Valine arylamidase & + & - & - \\
\hline$\alpha$-Chymotrypsin & - & - & w \\
\hline Acid phosphatase & - & - & + \\
\hline \multicolumn{4}{|l|}{ Susceptibility to antibiotics } \\
\hline Penicillin G & + & - & + \\
\hline Ampicillin & + & - & + \\
\hline Cephalothin & + & - & - \\
\hline Carbenicillin & + & - & + \\
\hline Novobiocin & + & + & - \\
\hline DNA G $+C$ content $(\mathrm{mol} \%)$ & 65.1 & $63.6-63.7^{a}, 64.4$ & 65.0 \\
\hline
\end{tabular}

${ }^{*}$ Data obtained from: a, Maruyama et al. (2006); b, Geueke et al. (2007).

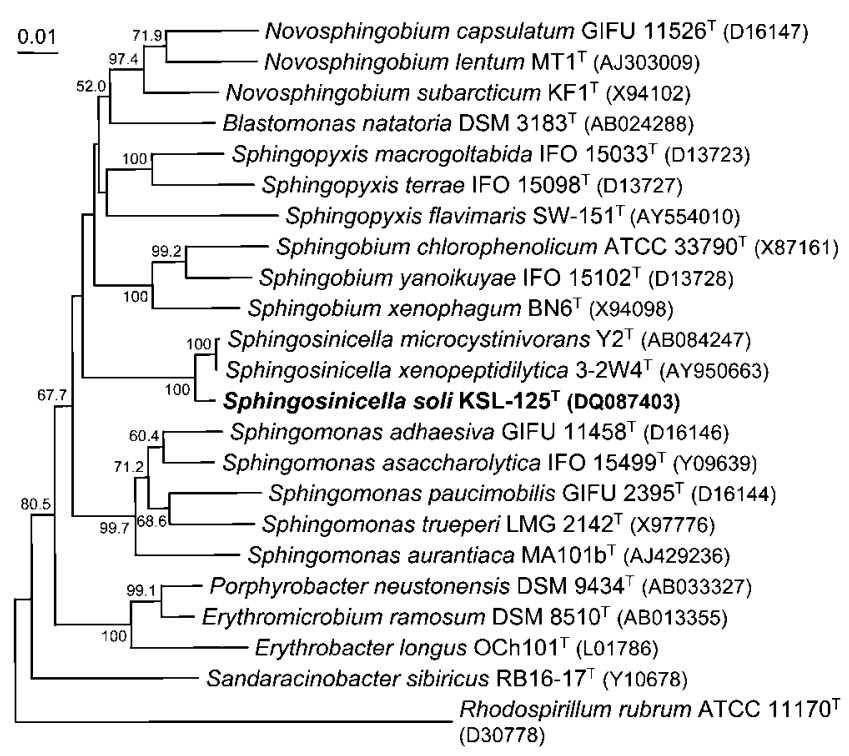

Fig. 1. Neighbour-joining phylogenetic tree, based on 16S rRNA gene sequences, showing the positions of strain $\mathrm{KSL}-125^{\top}$ and representatives of some related taxa. Bootstrap percentages (based on 1000 replications) $\geqslant 50 \%$ are shown at nodes. Rhodospirillum rubrum ATCC $11170^{\top}$ was used as an outgroup. Bar, 0.01 substitutions per nucleotide position.

Table 2. Cellular fatty acid compositions (\%) of strain KSL$125^{\top}$ and the type strains of the two Sphingosinicella species

Strains: 1, KSL- $125^{\mathrm{T}}$; 2, S. microcystinivorans KCTC $12019^{\mathrm{T}} ; 3, \mathrm{~S}$. xenopeptidilytica $3-2 \mathrm{~W} 4^{\mathrm{T}}$. Data are from this study. -, Not detected.

\begin{tabular}{|lccc|}
\hline Fatty acid & $\mathbf{1}$ & $\mathbf{2}$ & $\mathbf{3}$ \\
\hline Straight-chain fatty acids & & & \\
$\quad \mathrm{C}_{14: 0}$ & - & 1.2 & 1.2 \\
$\mathrm{C}_{15: 0}$ & 4.0 & - & - \\
$\mathrm{C}_{16: 0}$ & 4.1 & 6.3 & 7.4 \\
Unsaturated fatty acids & & & \\
$\mathrm{C}_{15: 1} \omega 6 c$ & 2.3 & - & - \\
$\mathrm{C}_{16: 1} \omega 5 c$ & 2.2 & 7.9 & 5.9 \\
$\mathrm{C}_{17: 1} \omega 6 c$ & 27.7 & 0.9 & 1.9 \\
$\mathrm{C}_{17: 1} \omega 8 c$ & 3.0 & - & - \\
$\mathrm{C}_{18: 1} \omega 5 c$ & - & 0.9 & 1.6 \\
$\mathrm{C}_{18: 1} \omega 7 c$ & 19.0 & 37.9 & 38.8 \\
$\mathrm{Hydroxy}$ fatty acids & & & \\
$\mathrm{C}_{14: 0} 2-\mathrm{OH}$ & 6.6 & 10.7 & 8.5 \\
$\mathrm{C}_{15: 0} 2-\mathrm{OH}$ & 5.6 & - & - \\
iso-C $16: 03-\mathrm{OH}$ & 2.3 & - & 1.8 \\
$11-\mathrm{Methyl} \mathrm{C}_{18: 1} \omega 7 c$ & - & - & 0.5 \\
Summed feature $3 *$ & 23.3 & 34.2 & 32.5 \\
\hline
\end{tabular}

* Summed features represent groups of two or three fatty acids that could not be separated by GLC with the MIDI system. Summed feature 3 contained $\mathrm{C}_{16: 1} \omega 7 c$ and/or iso- $\mathrm{C}_{15: 0} 2-\mathrm{OH}$. 


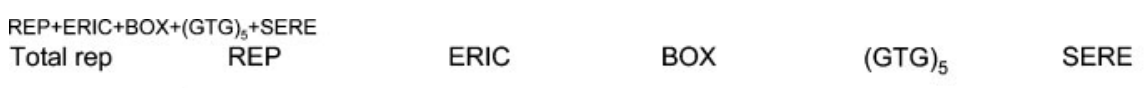

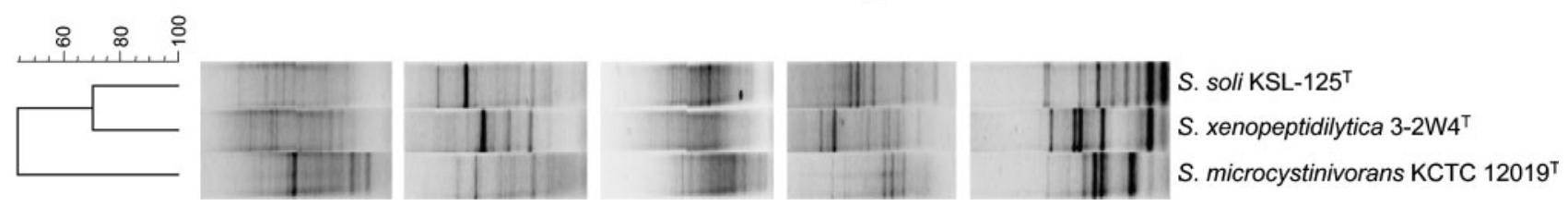

Fig. 2. Consensus dendrogram, based on similarity values obtained using the Jaccard correlation coefficient and the UPGMA algorithm in an analysis of the combined rep-PCR fingerprints generated by REP, ERIC, BOX, (GTG) 5 and SERE PCR primers, showing relationships among Sphingosinicella species.

unidentified glycolipid was also present. The DNA G $+\mathrm{C}$ content of strain KSL- $125^{\mathrm{T}}$ was $65.1 \mathrm{~mol} \%$.

Strain KSL- $125^{\mathrm{T}}$ could be distinguished from the two recognized Sphingosinicella species on the basis of differences in rep-PCR genomic fingerprinting patterns (Fig. 2). Strain KSL- $125^{\mathrm{T}}$ exhibited mean DNA-DNA relatedness values of 27 and $25 \%$ with respect to the type strains of $S$. microcystinivorans and S. xenopeptidilytica, respectively. These data indicate that strain KSL- $125^{\mathrm{T}}$ differs genetically from the two recognized Sphingosinicella species (Wayne et al., 1987). Strain KSL- $125^{\mathrm{T}}$ is also distinguishable from the two recognized Sphingosinicella species by differences in several phenotypic characteristics (Table 1). The phylogenetic and genetic distinctiveness and the differential phenotypic properties are sufficient to allocate strain KSL$125^{\mathrm{T}}$ to a species that is separate from the recognized Sphingosinicella species (Wayne et al., 1987; Table 1). Therefore, on the basis of the data presented, strain KSL$125^{\mathrm{T}}$ represents a novel species of the genus Sphingosinicella, for which the name Sphingosinicella soli sp. nov. is proposed.

\section{Description of Sphingosinicella soli sp. nov.}

Sphingosinicella soli (so'li. L. gen. n. soli of soil).

Cells are Gram-negative, non-spore-forming, short rods or rods, $0.3-0.5 \times 0.7-4.0 \mu \mathrm{m}$. Motile by means of single polar flagella. Colonies are circular, convex, smooth, glistening, yellow in colour and $0.5-1.0 \mathrm{~mm}$ in diameter after 7 days cultivation at $30{ }^{\circ} \mathrm{C}$ on TSA. The optimal growth temperature is $30{ }^{\circ} \mathrm{C}$; growth occurs at 4 and $37{ }^{\circ} \mathrm{C}$, but not at $38{ }^{\circ} \mathrm{C}$. The optimal $\mathrm{pH}$ for growth is 7.5-8.0; growth occurs at $\mathrm{pH} 6.0$ and 9.5, but not at $\mathrm{pH} 5.5$ or 10.0 . Optimal growth occurs in the presence of $0.5 \%(\mathrm{w} / \mathrm{v})$ $\mathrm{NaCl}$; growth occurs in the absence of $\mathrm{NaCl}$ and in the presence of $1 \%(\mathrm{w} / \mathrm{v}) \mathrm{NaCl}$ but not in the presence of $>2 \%(\mathrm{w} / \mathrm{v}) \mathrm{NaCl}$. Growth does not occur under anaerobic conditions on TSA or on TSA supplemented with nitrate. Tweens 20, 40 and 60 are hydrolysed. Casein, starch, hypoxanthine, L-tyrosine and xanthine are not hydrolysed. Lysine decarboxylase, ornithine decarboxylase and tryptophan deaminase are absent. Susceptible to polymyxin B, streptomycin, chloramphenicol, gentamicin, tetracycline, kanamycin and neomycin, but not to lincomycin or oleandomycin. Acetone/methanol extracts of freeze-dried cells show absorption maxima at $448-449$ and $476 \mathrm{~nm}$. The predominant ubiquinone is $\mathrm{Q}-10$. The major fatty acids (>10\% of total fatty acids) are $\mathrm{C}_{17: 1} 1 \omega 6 \mathrm{c}, \mathrm{C}_{16: 1} \omega 7 c$ and/or iso- $\mathrm{C}_{15: 0} 2-\mathrm{OH}$ and $\mathrm{C}_{18: 1} \omega 7 c$. The major polar lipids are sphingoglycolipid, diphosphatidylglycerol, phosphatidylglycerol, phosphatidylethanolamine, phosphatidylmonomethylethanolamine and an unidentified phospholipid. The DNA $\mathrm{G}+\mathrm{C}$ content is $65.1 \mathrm{~mol} \%$ (determined by HPLC). Other phenotypic characteristics are shown in Table 1 and Supplementary Table S1.

The type strain, KSL- $125^{\mathrm{T}}\left(=\mathrm{KCTC} 12482^{\mathrm{T}}=\mathrm{DSM}\right.$ $\left.17328^{\mathrm{T}}\right)$, was isolated from an alkaline soil from Kwangchun, Korea.

\section{Acknowledgements}

This work was supported by the 21C Frontier Program of Microbial Genomics and Applications (grant MG05-0401-2-0) from the Ministry of Science and Technology (MOST) of the Republic of Korea. We are grateful to Professor Hans-Jürgen Busse for providing the type strain $\left(3-2 \mathrm{~W} 4^{\mathrm{T}}\right)$ of S. xenopeptidilytica.

\section{References}

Cohen-Bazire, G., Sistrom, W. R. \& Stanier, R. Y. (1957). Kinetic studies of pigment synthesis by nonsulfur purple bacteria. J Cell Comp Physiol 49, 25-68.

Cowan, S. T. \& Steel, K. J. (1965). Manual for the Identification of Medical Bacteria. London: Cambridge University Press.

Geueke, B., Busse, H.-J., Fleischmann, T., Kämpfer, P. \& Kohler, H.-P. E. (2007). Description of Sphingosinicella xenopeptidilytica sp. nov., a $\beta$-peptide-degrading species, and emended descriptions of the genus Sphingosinicella and Sphingosinicella microcystinivorans. Int $J$ Syst Evol Microbiol 57, 107-113.

Komagata, K. \& Suzuki, K. (1987). Lipid and cell-wall analysis in bacterial systematics. Methods Microbiol 19, 161-207.

Lanyi, B. (1987). Classical and rapid identification methods for medically important bacteria. Methods Microbiol 19, 1-67.

Maruyama, T., Park, H.-D., Ozawa, K., Tanaka, Y., Sumino, T., Hamana, K., Hiraishi, A. \& Kato, K. (2006). Sphingosinicella microcystinivorans gen. nov., sp. nov., a microcystin-degrading bacterium. Int J Syst Evol Microbiol 56, 85-89. 
Minnikin, D. E., O'Donnell, A. G., Goodfellow, M., Alderson, G., Athalye, M., Schaal, A. \& Parlett, J. H. (1984). An integrated procedure for the extraction of bacterial isoprenoid quinones and polar lipids. J Microbiol Methods 2, 233-241.

Rademaker, J. L. W., Louws, F. J. \& de Bruijn, F. J. (1998). Characterization of the diversity of ecologically important microbes by rep-PCR genomic fingerprinting. In Molecular Microbial Ecology Manual, supplement 3, chapter 3.4.3, pp. 1-26. Edited by A. D. L. Akkermans, J. D. van Elsas \& F. J. de Bruijn. Dordrecht: Kluwer.

Rajashekara, G., Koeuth, T., Nevile, S., Back, A., Nagaraja, K. V., Lupski, J. R. \& Kapur, V. (1998). SERE, a widely dispersed bacterial repetitive DNA element. J Med Microbiol 47, 489-497.

Saito, T., Okano, K., Park, H.-D., Itayama, T., Inamori, Y., Neilan, B. A., Burns, B. P. \& Sugiura, N. (2003). Detection and sequencing of the microcystin LR-degrading gene, $m l r A$, from new bacteria isolated from Japanese lakes. FEMS Microbiol Lett 229, 271-276.

Sasser, M. (1990). Identification of bacteria by gas chromatography of cellular fatty acids, Technical Note 101. Newark, DE: MIDI.

Sneath, P. H. A. \& Sokal, R. R. (1973). Numerical Taxonomy. San Francisco: W. H. Freeman.
Tamaoka, J. \& Komagata, K. (1984). Determination of DNA base composition by reversed-phase high-performance liquid chromatography. FEMS Microbiol Lett 25, 125-128.

Versalovic, J., Schneider, M., de Brujin, F. J. \& Lupski, J. R. (1994). Genomic fingerprinting of bacteria using repetitive sequence-based polymerase chain reaction. Methods Mol Cell Biol 5, 25-40.

Wayne, L. G., Brenner, D. J., Colwell, R. R., Grimont, P. A. D., Kandler, O., Krichevsky, M. I., Moore, L. H., Moore, W. E. C., Murray, R. G. E. \& other authors (1987). International Committee on Systematic Bacteriology. Report of the ad hoc committee on reconciliation of approaches to bacterial systematics. Int J Syst Bacteriol 37, 463-464.

Yoon, J.-H., Kim, H., Kim, S.-B., Kim, H.-J., Kim, W. Y., Lee, S. T., Goodfellow, M. \& Park, Y.-H. (1996). Identification of Saccharomonospora strains by the use of genomic DNA fragments and rRNA gene probes. Int J Syst Bacteriol 46, 502-505.

Yoon, J.-H., Lee, S. T. \& Park, Y.-H. (1998). Inter- and intraspecific phylogenetic analysis of the genus Nocardioides and related taxa based on 16S rRNA gene sequences. Int J Syst Bacteriol 48, 187-194.

Yoon, J.-H., Kim, H., Kim, I.-G., Kang, K. H. \& Park, Y.-H. (2003). Erythrobacter flavus sp. nov., a slight halophile from the East Sea in Korea. Int J Syst Evol Microbiol 53, 1169-1174. 